\title{
KERAGAAN DAN POTENSI HASIL KARET DARI BEBERAPA GENOTIPE HASIL PERSILANGAN ANTAR TETUA TANAMAN BERKERABAT JAUH
}

\author{
Performance and Rubber Yield Potential of Some Genotypes Crossing Coming from \\ Among Far Genetic Relationship Parental Clones \\ SAYURANDI ${ }^{11}$ dan Sekar WOELAN ${ }^{21}$ \\ ${ }^{11}$ Balai Penelitian Sungei Putih, Pusat Penelitian Karet \\ PO.Box 1415, Medan 20001 Sumatera Utara \\ Email: sayurandi_sp@yahoo.com \\ ${ }^{2)}$ Pusat Penelitian Karet \\ Jalan Salak No 1 Bogor 16151 \\ Email : sekaryudi@yahoo.com
}

Diterima : 25 November 2014 / Direvisi : 18 Januari 2015 / Disetujui : 15 Maret 2015

\begin{abstract}
Rubber plant breeding and selection progress depends very much on potency and source of genetic variability. Genetic variability can be obtained from crossing activity among parental clones which have far genetic relationship. The purpose of this study was to determine the performance of plant growth and dry rubber yield potential of rubber genotypes coming from crossing result of rubber parental clones which have long genetic relationship in seedling evaluation trial. A total of 62 genotypes crossing result were used in this research. RRIM 600, IAN 873, IRR 111, PB 260, RRII 105, PM 10, IRR 104, and IRR 220 clones were used as female parental clones derived from Wickham's population, while PN 4267, PN 3508, PN 4143, PN 3760, PN 3763, PN 5009, PN 1682 and $P N$ 2157 clones were used as male parental clones derived from IRRDB expedition in 1981. The F1 genotypes population were planted at Sungei Putih Research Centre Experimental Garden, Indonesian Rubber Research Institute in 2003 with planting distance $2 \times 2 \mathrm{~m}$. The evaluation was done on plant growth, bark anatomy, and dry rubber yield potential. Analysis result showed that the variation was significant for five variables observed, with coefficient of variance of dry rubber yield $77.10 \%$, girth 29.32\%, barkthickness 26,47\%, number of latex vessel rings $27.44 \%$, and diameter of latex vessel cells $17.16 \%$. The genotype G17 and G80/2 were the plants which had higher dry rubber yield potential than other genotypes which were 37.00 $\mathrm{g} / \mathrm{t} / \mathrm{t}$ and $22.50 \mathrm{~g} / \mathrm{t} / \mathrm{t}$ respectively. The two genotypes also had vigorous plant growth, were
\end{abstract}

their girth size were $67 \mathrm{~cm}$ and $71.5 \mathrm{~cm}$ at ten years old, respectivelty.

Keywords: Hevea brasilliensis, far genetic relationship, genetic variability, growth, dry rubber yield

Abstrak
Kemajuan pemuliaan dan seleksi
tanaman karet sangat bergantung kepada potensi
dan ketersediaan sumber keragaman genetik.
Keragaman genetik dapat dihasilkan melalui
kegiatan persilangan antar tetua yang memiliki
hubungan kekerabatan jauh. Tujuan penelitian
ini adalah untuk mengevaluasi keragaan
tanaman dan potensi hasil karet kering dari
genotipe hasil persilangan berkerabat jauh di
pengujian evaluasi semaian. Sebanyak 62
genotipe hasil persilangan digunakan dalam
penelitian ini. Sebagai tetua betina digunakan
klon yang berasal dari populasi Wickham yaitu
RRIM 600, IAN 873, IRR 111, PB 260, RRII 105,
PM 10, IRR 104, dan IRR 220, sedangkan sebagai
tetua jantan digunakan genotipe yang berasal
dari ekspedisi IRRDB 1981 di antaranya PN
4267, PN 3508, PN 4143, PN 3760, PN 3763, PN
5009, PN 1682 dan PN 1527. Populasi genotipe F1
tersebut ditanam di Kebun Percobaan Balai
Penelitian Sungei Putih, Pusat Penelitian Karet
pada tahun 2003 dengan menggunakan jarak
tanam 2 x 2 m. Evaluasi dilakukan terhadap
karakter pertumbuhan tanaman, anatomi kulit,


dan potensi hasil karet. Hasil analisis menunjukkan keragaman yang cukup signifikan pada lima sifat yang diamati dengan koefisien keragaman hasil karet kering $77,10 \%$, lilit batang $29,32 \%$, ukuran tebal kulit $26,47 \%$, jumlah cincin pembuluh lateks $27,44 \%$, dan diameter sel pembuluh lateks 17,16\%. Genotipe G-17 dan G$80 / 2$ merupakan tanaman yang memiliki potensi hasil karet paling tinggi dibandingkan genotipe lainnya, masing-masing sebesar $37,00 \mathrm{~g} / \mathrm{p} / \mathrm{s}$ dan $22,50 \mathrm{~g} / \mathrm{p} / \mathrm{s}$. Kedua genotipe tersebut juga memiliki pertumbuhan tanaman paling jagur, dengan ukuran lilit batang tanaman yaitu 67,00 $\mathrm{cm}$ dan $71,50 \mathrm{~cm}$ pada umur sepuluh tahun.

Kata kunci: Hevea brasiliensis, kekerabatan jauh, keragaman genetik, pertumbuhan, hasil karet kering

\section{PENDAHULUAN}

Aktifitas pemuliaan tanaman karet di Indonesia terus dilakukan untuk memperoleh klon-klon unggul baru yang lebih produktif dan memiliki karakter agronomis yang diinginkan. Klon unggul biasanya diperoleh melalui seleksi terhadap populasi turunan pertama dari hasil suatu persilangan. Seleksi pada turunan pertama ini sangat penting dan sebagai dasar untuk melakukan tahapan pengujian selanjutnya. Seleksi tanaman secara fenotipik pada suatu populasi tanaman hasil persilangan dapat dilakukan dengan melihat penampilan populasi dari suatu populasi tanaman (Borojevic, 1990; Mangoendidjojo, 2002).

Klon karet yang berkembang pada saat ini merupakan klon unggul yang dihasilkan dari pemuliaan dan seleksi terhadap populasi tanaman hasil ekspedisi Henry Wickham pada tahun 1876. Sampai dengan saat ini, produktivitas tanaman yang dapat dicapai dari klon-klon unggul tersebut sekitar 2500-3000 kg/ha/th. Produktivitas tersebut masih jauh dari potensi tanaman karet sesungguhnya. Menurut Aziz (1998), secara teoritis produktivitas karet dapat mencapai $7000 \mathrm{~kg} / \mathrm{ha} / \mathrm{th}$, sedangkan menurut Ho (1975), potensi produksi tanaman karet dapat mencapai 10 ton/ha/th.

Lambatnya kenaikan produktivitas tersebut menurut Madjid (1985) adalah karena sangat terbatasnya sumber genetik akibat dari persilangan yang dilakukan secara terus menerus pada populasi Wickham 1876, sehingga keturunan tanaman yang dihasilkan mengalami tekanan silang dalam (inbreeding depression). Menurut peneliti yang sama, keterbatasan dalam pembentukan variabilitas genetik merupakan faktor pembatas dalam menaikkan produktivitas klon karet. Dengan demikian, agar klonklon unggul baru dapat dihasilkan maka sumber keragaman genetik karet yang tersedia perlu diperluas. Upaya perakitan genotipe baru melalui persilangan perlu secara terus-menerus dilakukan.

Dalam upaya memperbesar variabilitas genetik karet, Indonesia telah bekerjasama dengan negara anggota IRRDB (International Rubber Research and Development Board). Antara tahun 1981 1989 Indonesia telah menerima 7788 genotipe material plasma nutfah karet hasil ekspedisi IRRDB di Lembah Amazon, Brazil. Genotipe-genotipe tanaman tersebut telah dikoleksi secara ex-situ di Kebun Percobaan Balai Penelitian Sungei Putih, Sumatera Utara. Dari hasil evaluasi terhadap sifat pertumbuhan dan hasil karet kering diketahui bahwa tidak ditemukan genotipe tanaman yang memiliki potensi hasil lateks tinggi. Laporan Aidi-Daslin et al. (2002) menyebutkan beberapa genotipe memiliki pertumbuhan jagur, tetapi hasil lateks sangat rendah. Hasil penelitian yang sama juga telah dilaporkan Ong et al. (1995). Namun demikian, potensi plasma nutfah IRRDB perlu dimanfaatkan secara maksimal dan sistematis melalui program persilangan buatan untuk menghasilkan klon unggul penghasil lateks-kayu dan tahan penyakit.

Kemajuan pemuliaan dan seleksi tanaman karet sangat bergantung kepada potensi dan ketersediaan sumber keragaman genetik. Untuk menciptakan keragaman genetik yang luas, di antaranya dapat dilakukan melalui kegiatan persilangan buatan (hibridisasi) yang bertujuan untuk mendapatkan turunan yang memiliki sifat unggul. Dari hasil persilangan diharapkan munculnya beberapa genotipe baru yang mewarisi sifat unggul dari ke dua tetuanya. Tingkat variabilitas genetik yang dihasilkan tergantung pada hubungan kekerabatan genetik dari tetua yang digunakan dalam 
persilangan (Sayurandi dan Aidi-Daslin, 2011). Berdasarkan analisis DNA dengan menggunakan teknik RAPD menunjukkan bahwa klon asal populasi Wickham 1876 memiliki hubungan kekerabatan genetik cukup jauh dengan plasma nutfah IRRDB 1981 (Oktavia et al., 2010). Dengan persilangan antar tetua berkerabat jauh diharapkan dapat dihasilkan turunan yang lebih unggul yang terekspresi melalui heterosis kepada keturunan pertamanya.

Penelitian ini bertujuan untuk mengetahui keragaan pertumbuhan dan potensi hasil karet kering dari genotipe karet hasil persilangan tetua karet berkerabat jauh di pengujian evaluasi semaian.

\section{BAHAN DAN METODE}

Penelitian ini menggunakan sebanyak 62 genotipe $\mathrm{F} 1$ hasil persilangan dari tetua berkerabat jauh. Klon RRIM 600, IAN 873, IRR 111, PB 260, RRII 105, PM 10, IRR 104, dan IRR 220 digunakan sebagai tetua betina yang merupakan hasil seleksi dari populasi Wickham 1876, sedangkan klon PN 4267, PN 3508, PN 4143, PN 3760, PN 3763, PN 5009, PN 1682 dan PN 2157 digunakan sebagai tetua jantan yang berasal dari hasil ekspedisi plasma nutfah IRRDB tahun 1981. Genotipe F1 hasil persilangan ditanam di kebun percobaan Balai Penelitian Sungei Putih pada tahun 2003 dengan jarak tanam $2 \times 2$ meter seperti disajikan pada Tabel 1.

Tabel 1. Genotipe hasil persilangan dari tetua asal populasi Wickham 1876 dan plasma nutfah IRRDB 1981

Table 1. Genotypes crossing result of the parental origin of Wickham 1876 population and IRRDB 1981 germplasm

\begin{tabular}{|c|c|c|c|}
\hline No & $\begin{array}{l}\text { Tetua } \\
\text { Parents }\end{array}$ & $\begin{array}{c}\text { Jumlah } \\
\text { genotipe } \\
\text { Number of } \\
\text { genotypes }\end{array}$ & $\begin{array}{l}\text { Nomor genotipe } \\
\text { Genotypes number }\end{array}$ \\
\hline 1. & IAN 873 X PN 4267 & 2 & G-66, G-67 \\
\hline 2. & IAN 873 X PN 3508 & 4 & G-38, G-39, G-40, G-60 \\
\hline 3. & IAN 873 X PN 4134 & 1 & G-104 \\
\hline 4. & RRIM 600 X PN 4267 & 2 & G-72, G-73/1 \\
\hline 5. & RRIM 600 X PN 4134 & 5 & $\mathrm{G}-84 / 1, \mathrm{G}-87, \mathrm{G}-85, \mathrm{G}-84 / 2, \mathrm{G}-83 / 1$ \\
\hline 6. & RRIM 600 X PN 3762 & 2 & $\mathrm{G}-24, \mathrm{G}-52$ \\
\hline 7. & IAN 873 X PN 3760 & 34 & $\begin{array}{l}\text { G-32, G-33, G-36, G-37, G-39, G-80, G- } \\
\text { 79, G-76, G-75, G-74, G-73/2, G-69, G- } \\
\text { 68, G-67, G-57, G-56, G-55, G-54, G-53, } \\
\text { G-50, G-48, G-47, G-41, G-81, G-82, G- } \\
\text { 83/2, G-115, G-120, G-150, G-146, G- } \\
\text { 136, G-135, G-130, G-128 }\end{array}$ \\
\hline 8. & IRR 111 X PN 5009 & 2 & G-80/2, G-186 \\
\hline 9. & PB 260 X PN 5009 & 2 & G-356, G-548 \\
\hline 10. & PM 10 X PN 2157 & 1 & G-38 \\
\hline 11. & RRII 105 X PN 1682 & 2 & G-107, G-482 \\
\hline 12. & IRR 220 X PN 1682 & 1 & G-02 \\
\hline 13. & IRR 220 X PN 5009 & 1 & G-700 \\
\hline 14. & IRR 104 X PN 1682 & 3 & G-17, G-404, G-666 \\
\hline & Total & 62 & \\
\hline
\end{tabular}


Populasi tanaman yang diamati merupakan tanaman yang belum pernah disadap sebelumnya. Pengamatan dilakukan pada setiap genotipe tanaman. Parameter lilit batang dan tebal kulit diukur pada ketinggian $50 \mathrm{~cm}$ di atas permukaan tanah (dpt). Jumlah cincin pembuluh lateks dan diameter sel pembuluh lateks diamati dengan menggunakan metode Gomez et al. (1972), dengan cara mengambil contoh kulit berdiameter $1 \mathrm{~cm}$ pada ketinggian $50 \mathrm{~cm}$ dpt. Potensi hasil dihitung berdasarkan berat karet kering per pohon per sadap $(\mathrm{g} / \mathrm{p} / \mathrm{s})$ dengan menggunakan sistem sadap $\mathrm{S} / 2 \mathrm{~d} 3$ pada ketinggian $50 \mathrm{~cm}$ dpt selama enam bulan yaitu bulan Januari - Juni 2013.

Data hasil penelitian pada Tabel 1 dianalisis menggunakan statistik dengan memanfaatkan program MINITAB ver. 16 untuk mendapatkan nilai tengah, minimum, maksimum, standar deviasi dan koefisien keragaman dari populasi tanaman $\mathrm{F} 1$ yang diuji. Nomor genotipe tanaman hasil persilangan antara klon populasi Wickham 1876 dan plasmanutfah IRRDB 1981.

\section{HASIL DAN PEMBAHASAN}

Analisis statistik terhadap hasil pengamatan pertumbuhan tanaman, anatomi kulit dan hasil karet kering dari genotipe hasil persilangan asal populasi Wickham 1876 dan plasma nutfah IRRDB 1981 disajikan pada Tabel 2. Dari hasil pengamatan menunjukkan bahwa hasil karet kering dari genotipe tersebut sangat bervariasi dengan koefisien keragaman (KK) sebesar $77,10 \%$. Sifat lain yang diamati juga menunjukkan keragaman yang cukup tinggi dengan kisaran keragaman antara 17,16 $29,32 \%$. Diantara semua sifat yang diamati, peubah diameter sel pembuluh lateks menunjukkan keragaman yang paling rendah, yaitu $17,16 \%$. Rata-rata diameter sel pembuluh lateks 29,02 $\mu \mathrm{m}$. Hal ini menunjukkan bahwa diameter sel pembuluh lateks lebih seragam diantara genotipe tanaman dibandingkan dengan karakter lainnya. Koefisien keragaman yang rendah pada diameter sel pembuluh lateks juga sudah pernah dilaporkan sebelumnya (Goncalves et al., 2005; Novalina, 2009).

Tabel 2. Hasil analisis statistik terhadap 5 sifat penting dari 62 genotipe yang diuji Table 2. Statistic analysis result to 5 important characters of 62 genotypes were tested

\begin{tabular}{lccccc}
\hline \multicolumn{1}{c}{$\begin{array}{c}\text { Deskripsi statistik } \\
\text { Statistic description }\end{array}$} & $\begin{array}{c}\text { Lilit } \\
\text { batang } \\
\text { Girth } \\
(\mathrm{cm})\end{array}$ & $\begin{array}{c}\text { Tebal kulit } \\
\text { Bark } \\
\text { Thickness } \\
(\mathrm{mm})\end{array}$ & $\begin{array}{c}\text { cincin } \\
\text { pembuluh } \\
\text { lateks } \\
\text { Number of } \\
\text { latex vessel } \\
\text { rings }\end{array}$ & $\begin{array}{c}\text { Diameter sel } \\
\text { pembuluh } \\
\text { lateks } \\
\text { Diameter of } \\
\text { latex vessel } \\
\text { cells } \\
(\mu \mathrm{m})\end{array}$ & $\begin{array}{c}\text { Hasil } \\
\text { lateks } \\
(\mathrm{g} / \mathrm{p} / \mathrm{s}) \\
\text { Latex } \\
\text { yield } \\
(\mathrm{g} / \mathrm{t} / \mathrm{t})\end{array}$ \\
\hline $\begin{array}{l}\text { Nilai Tengah } \\
\begin{array}{l}\text { Mean } \\
\text { Minimum }\end{array}\end{array}$ & 43,36 & 4,19 & 4,86 & 29,02 & 4,86 \\
$\begin{array}{l}\text { Minimum } \\
\text { Maksimum }\end{array}$ & 21,50 & 2,50 & 3,00 & 16,88 & 0,80 \\
$\begin{array}{l}\text { Maximum } \\
\text { Simpangan Baku } \\
\text { Deviation standard }\end{array}$ & 73,00 & 7,00 & 9,50 & 46,25 & 37,40 \\
$\begin{array}{l}\text { Koefisien Keragaman } \\
\text { (KK) }\end{array}$ & 12,71 & 1,11 & 1,33 & 4,98 & 3,75 \\
$\begin{array}{l}\text { Coefficient of variability } \\
\text { (CV) }\end{array}$ & 29,32 & 26,47 & 27,44 & 17,16 & 77,10 \\
\hline
\end{tabular}


Terdapatnya keragaman genetik yang tinggi pada hasil persilangan populasi Wickham 1876 dan plasma nutfah IRRDB 1981 diduga lebih diakibatkan oleh faktor genetik. Hal ini dapat dipahami mengingat tetua betina dan tetua jantan memiliki kekerabatan genetik yang jauh (Oktavia et al., 2010). Klon yang digunakan sebagai tetua betina seperti RRIM 600, IAN 873, IRR 111, PB 260, RRII 105, PM 10, IRR 104, dan IRR 220 merupakan hasil pemuliaan tanaman asal populasi Wickham pada tahun 1876, sedangkan klon yang digunakan sebagai tetua jantan seperti PN 4267, PN 3760, PN 3763, PN 1682, PN 5009, dan PN 2157 merupakan hasil ekspedisi IRRDB pada tahun 1981. Selain itu diduga juga diakibatkan oleh sifat heterozigot pada tanaman karet, sehingga gen-gen yang terlibat pada penampilan suatu karakter tanaman akan bersegregasi pada populasi turunan pertama (Novalina, 2009: Sayurandi dan Aidi-Daslin, 2011).

Pola penyebaran genotipe tanaman hasil persilangan populasi Wickham 1876 dan Plasma nutfah IRRDB 1981 berdasarkan sifat pertumbuhan tanaman, anatomi kulit dan hasil lateks (Gambar 1).

Pada Gambar 1 menunjukkan bahwa kelima karakter yang diamati dari 62 genotipe tanaman tidak semuanya menyebar secara normal. Ukuran lilit batang
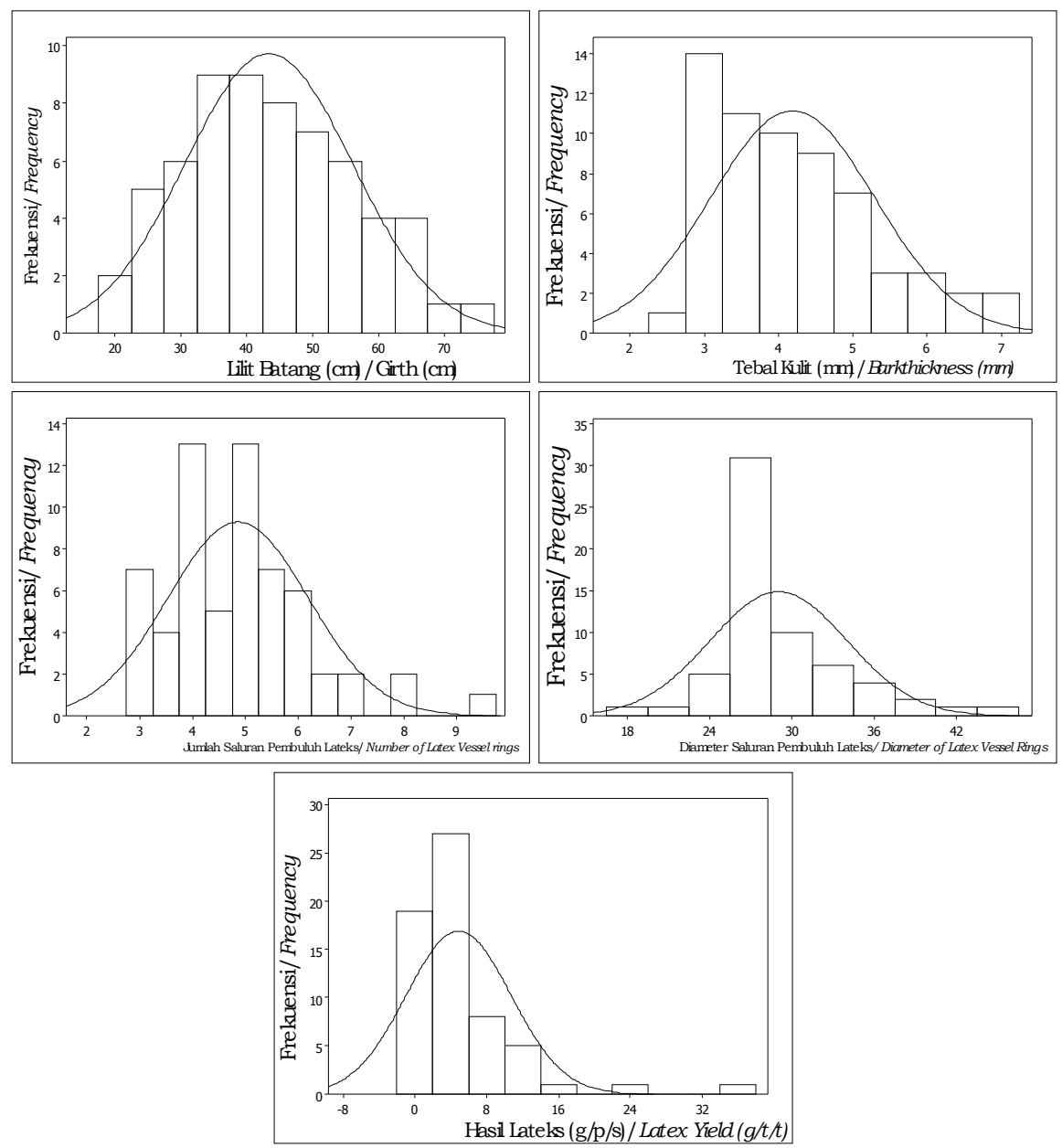

Gambar 1. Sebaran lilit batang, tebal kulit, jumlah dan diameter saluran pembuluh lateks, dan hasil karet kering dari 62 genotipe tanaman hasil persilangan.

Figure 1. Distributions of girth, bark thickness, number and diameter of latex vessels, and dry rubber yield of 62 genotypes crossing result 
tanaman memiliki nilai tengah sebesar 43,36 cm dengan kisaran 21,50-73,00 cm. Hal tersebut menunjukkan bahwa ukuran lilit batang cukup beragam (KK= 29,32\%). Keragaman yang timbul dapat dipahami, karena tetua betina memiliki pertumbuhan lilit batang yang lebih rendah, sedangkan tetua jantan memiliki pertumbuhan jagur, sehingga keturunannya memiliki penampilan rata-rata dari kedua tetua (Crowder, 1986).

Karakter tebal kulit memiliki nilai tengah sebesar 4,19 $\mathrm{mm}$ dengan kisaran 2,50 - 7,00 mm. Karakter tebal kulit juga menunjukkan keragaman yang cukup tinggi dengan KK sebesar 26,47\%. Karakter anatomi kulit yang memiliki keragaman yang cukup tinggi yaitu jumlah cincin pembuluh lateks $(\mathrm{KK}=27,44 \%)$, dengan nilai tengah sebesar 4,86 cincin dan kisaran 3,00 - 9,50 cincin. Anatomi kulit merupakan salah satu karakter penting untuk menyeleksi genotipe tanaman karet. Jumlah cincin pembuluh lateks dan diameter sel pembuluh lateks merupakan karakter yang paling penting. Hal ini karena biosintesis lateks pada tanaman karet berlangsung pada sel-sel pembuluh lateks (d'Auzac, 2008).

Pada Gambar 1 juga menunjukkan bahwa hasil karet kering menyebar normal dengan nilai tengah sebesar $4,86 \mathrm{~g} / \mathrm{p} / \mathrm{s}$. Keragaman fenotipe yang dihasilkan dari karakter hasil karet kering paling tinggi dibandingkan dengan karakter lainnya. Tingginya keragaman yang terbentuk memberikan indikasi bahwa banyak faktor yang berperan di dalam penentuan hasil lateks. Menurut Woelan dan Azwar (1990), peluang memperoleh klon unggul akan lebih besar apabila keragaman genetik yang terbentuk tinggi.

Hasil penyadapan pada populasi tanaman di pembibitan yang diamati juga mengalami variasi lingkungan. Hasil karet kering $(\mathrm{g} / \mathrm{p} / \mathrm{s})$ selama 6 bulan penyadapan dari beberapa genotipe yang memiliki hasil karet kering $(\mathrm{g} / \mathrm{p} / \mathrm{s})$ tergolong rendah, sedang, dan tinggi pada populasi tanaman disajikan pada Gambar 2.

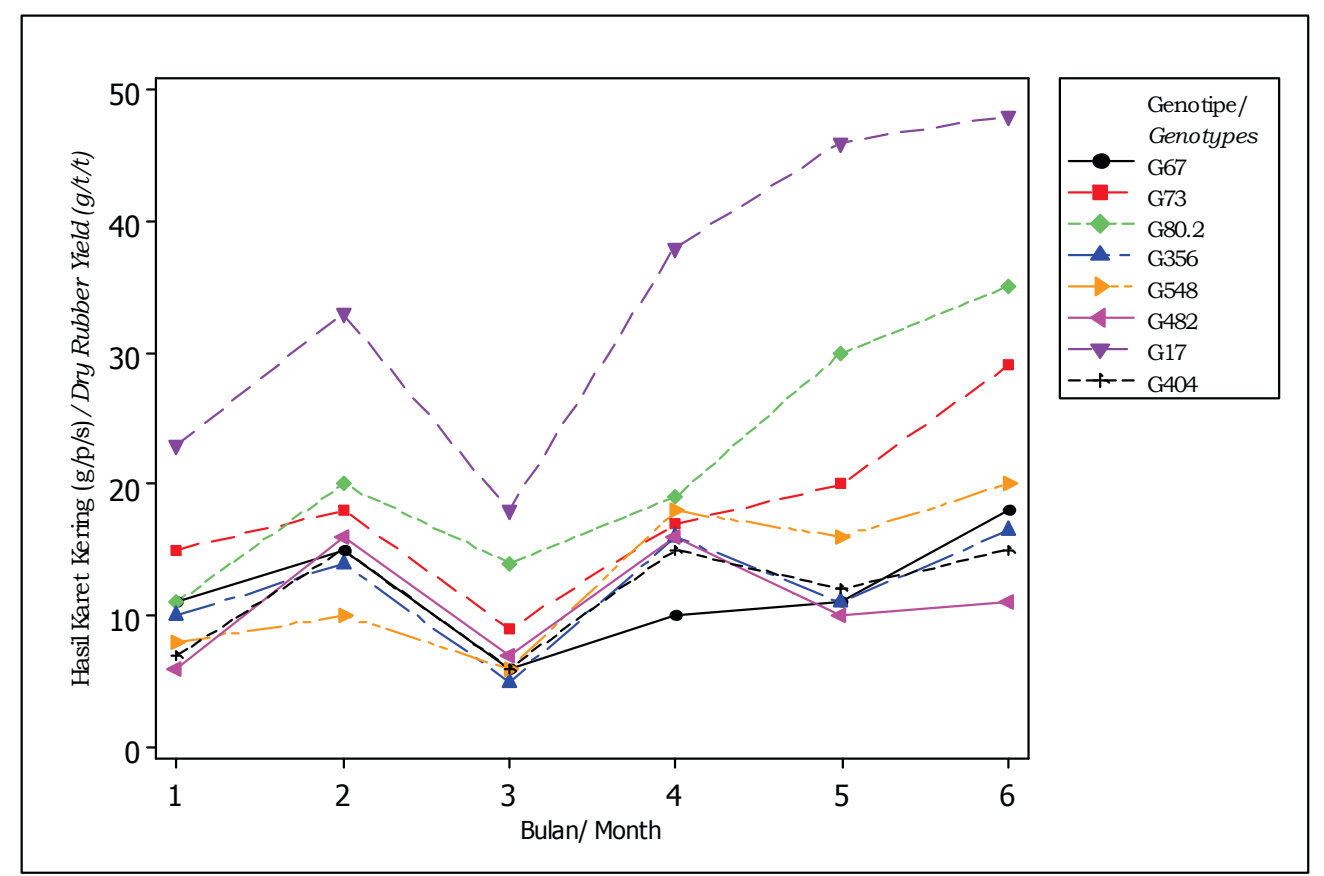

Gambar 2. Hasil karet kering (g/p/s) selama 6 bulan penyadapan dari 8 genotipe hasil persilangan.

Figure 2. Dry rubber yield $(\mathrm{g} / \mathrm{t} / \mathrm{t})$ during 6 months of tapping of 8 genotypes crossing result. 
Gambar 2 menunjukkan bahwa pada awal penyadapan hampir semua genotipe memiliki produksi yang rendah. Pada bulan kedua penyadapan sudah tampak tanamantanaman yang memiliki potensi produksi tinggi dibandingkan dengan genotipe tanaman lainnya. Sebagian besar tanaman mengalami hasil sadap terendah pada bulan Maret. Rendahnya hasil sadap pada bulan tersebut sangat berkaitan dengan musim gugur daun tanaman pada areal seleksi. Berdasarkan pengamatan di lapangan genotipe yang diamati sudah mengalami musim gugur daun pada akhir Februari. Di wilayah Sumatera Utara pada umumnya gugur daun terjadi pada bulan Februari April. Menurut Siregar et al., (2007) dinamika gugur daun dan produksi karet sejalan dengan jumlah daun yang rontok yang ditentukan oleh kandungan air tanah.

Pada umumnya, genotipe tanaman memperlihatkan hasil tertinggi pada bulan Juni. Hal ini mungkin berkaitan dengan telah sempurnanya pertumbuhan daun serta kondisi iklim yang mungkin optimal pada periode tersebut. Daun-daun yang sudah berkembang sempurna dan dalam kondisi masih segar akan mampu menjalankan proses fotosintesis dengan baik, sehingga berbagai proses metabolisme dapat berjalan dengan lancar. Berdasarkan hasil pengamatan genotipe G-17 selalu menunjukkan hasil tertinggi pada setiap bulan pengamatan dibandingkan dengan genotipe lainnya selama berlangsungnya pengamatan produksi. Di samping itu tampak beberapa genotipe memiliki hasil yang rendah dan stabil selama enam bulan penyadapan. Hal ini mengindikasikan bahwa terdapatnya keragaman dalam hal produksi lateks diantara tanaman-tanaman turunan pertama yang diamati diakibatkan oleh faktor genetik.

Data pertumbuhan lilit batang, anatomi kulit, dan hasil karet kering dari sembilan genotipe yang memiliki nilai di atas rata-rata populasi tanaman disajikan pada Tabel 3. Berdasarkan hasil pengamatan

Tabel 3. Pertumbuhan lilit batang, anatomi kulit, dan hasil lateks dari 9 genotipe umur sepuluh tahun.

Table 3. Girth growth, bark anatomy, and latex yield of 9 genotypes at ten years old.

\begin{tabular}{|c|c|c|c|c|c|c|}
\hline $\begin{array}{l}\text { Genotipe } \\
\text { Genotypes }\end{array}$ & $\begin{array}{c}\text { Tetua } \\
\text { Parents }\end{array}$ & $\begin{array}{c}\text { Lilit } \\
\text { batang } \\
\text { Girth } \\
(\mathrm{cm})\end{array}$ & $\begin{array}{c}\text { Tebal } \\
\text { kulit } \\
\text { Bark } \\
\text { thickness } \\
(\mathrm{mm})\end{array}$ & $\begin{array}{l}\text { Jumlah } \\
\text { cincin } \\
\text { pembuluh } \\
\text { lateks } \\
\text { Number of } \\
\text { latex } \\
\text { vessel } \\
\text { rings }\end{array}$ & $\begin{array}{c}\text { Diameter } \\
\text { sel } \\
\text { pembuluh } \\
\text { lateks } \\
\text { Diameter } \\
\text { of latex } \\
\text { vessel } \\
\text { cells } \\
(\mu \mathrm{m})\end{array}$ & $\begin{array}{c}\text { Rata-rata } \\
\text { hasil karet } \\
\text { kering } \\
\text { (g/p/s) } \\
\text { selama } 6 \\
\text { bulan } \\
\text { Dry rubber } \\
\text { yield } \\
\text { average } \\
(g / t / t) \text { for } 6 \\
\text { months }\end{array}$ \\
\hline G-67 & IAN $873 \times$ PN 4267 & 62,50 & 5,50 & 6,00 & 29,13 & 10,34 \\
\hline G-73 & RRIM 600 x PN 4267 & 56,50 & 4,50 & 9,50 & 35,00 & 16,72 \\
\hline $\mathrm{G}-80 / 2$ & IRR 111 X PN 5009 & 71,50 & 6,50 & 8,00 & 31,25 & 22,5 \\
\hline G-186 & IRR 111 X PN 5009 & 44,50 & 6,50 & 5,00 & 43,13 & 6,8 \\
\hline G-38 & PM 10 X PN 2157 & 55,00 & 7,00 & 6,00 & 36,88 & 8,1 \\
\hline G-482 & RRII 105 X PN 1682 & 53,50 & 6,50 & 6,00 & 38,13 & 10,1 \\
\hline G-02 & IRR 220 X PN 1682 & 63,00 & 6,00 & 7,00 & 31,25 & 7,8 \\
\hline G-17 & IRR 104 X PN 1682 & 67,00 & 6,00 & 7,00 & 29,75 & 37,4 \\
\hline G-404 & IRR 104 X PN 1682 & 59,50 & 6,00 & 4,90 & 46,25 & 10,3 \\
\hline
\end{tabular}


sangat sulit memastikan potensi produksi karet kering dalam satuan $\mathrm{kg} / \mathrm{ha} / \mathrm{th}$, mengingat tidak terdapatnya ulangan dari masing-masing tanaman turunan pertama tersebut. Dengan demikian data pengamatan rata-rata produksi karet kering selama 6 bulan dihitung dalam satuan gram/pohon/sadap (g/p/s).

Tabel 3 menunjukkan bahwa berdasarkan karakter ukuran lilit batang tanaman, genotipe G-80/2 dan G-17 memiliki pertumbuhan lilit batang paling jagur yaitu masing-masing sebesar $71,50 \mathrm{~cm}$ dan $67,00 \mathrm{~cm}$ pada umur sepuluh tahun, sedangkan yang paling rendah terdapat pada genotipe G-186 yaitu sebesar 44,50 $\mathrm{cm}$. Ukuran tebal kulit dari 9 genotipe cukup bervariasi dengan ukuran tebal kulit berkisar 4,50 - 7,00 mm, demikian halnya dengan karakter jumlah cincin pembuluh lateks dan diameter sel pembuluh lateks memiliki nilai cukup beragam. Jumlah cincin pembuluh lateks berkisar 4,90-9,50 cincin, dan diameter sel pembuluh lateks berkisar 29,13-46,25 $\mu \mathrm{m}$.

Pada Tabel 3 juga menunjukkan bahwa potensi hasil karet kering tertinggi dimiliki oleh genotipe G-17 dan G-80/2 dengan potensi hasil karet kering sebesar $37,00 \mathrm{~g} / \mathrm{p} / \mathrm{s}$ dan $22,50 \mathrm{~g} / \mathrm{p} / \mathrm{s}$. Jika dilihat dari potensi hasil lateks ternyata genotipe hasil persilangan populasi Wickham 1876 dan plasma nutfah IRRDB 1981 menunjukkan potensi hasil karet kering masih jauh dibawah potensi hasil karet kering pada klon-klon yang sudah dibudidayakan saat ini. Meskipun demikian, genotipe ini masih perlu dipertimbangkan sebagai tanaman yang dapat dimasukkan ke dalam kelompok tanaman terpilih di antara semua tanaman turunan pertama yang ada pada areal seleksi saat ini. Genotipe G-17 dan G-80/2 selain memiliki potensi hasil lateks tertinggi diantara populasi yang ada, ternyata kedua genotipe juga memiliki pertumbuhan lilit batang cukup jagur dibandingkan dengan genotipe lainnya. Jika dilihat dari pertumbuhan tanaman dan potensi hasil karet kering, maka genotipe G17 dan G- 80/2 dapat dikategorikan sebagai genotipe penghasil lateks-kayu.

Dari hasil seleksi di pengujian F1 perlu dilakukan pengujian lanjutan untuk melihat potensi tanaman dalam skala yang lebih luas. Perlu dipahami bahwa tanaman
F1 yang ditanam pada areal seleksi dengan jarak 2 × 2 m belum dapat menampilkan potensi produksi yang optimal. Tanaman F1 hasil persilangan ditanam pada jarak tanam yang lebih sempit dibandingkan dengan jarak tanam yang dianjurkan yaitu 6 × $3 \mathrm{~m}$ disebabkan keterbatasan areal penanaman. Tujuan utaman pada pengujian F1 ini adalah hanya untuk menyeleksi genotipegenotipe yang memiliki potensi hasil tinggi.

Genotipe hasil persilangan yang ditanam pada jarak tanam yang sempit akan menyebabkan terjadinya kompetisi tinggi antar tanaman, baik terhadap penyerapan hara dan air tanah maupun kompetisi ruang untuk pertumbuhan tanaman. Dijkman (1951) menyatakan bahwa tanaman karet yang ditanam pada jarak tanam yang lebih jarang akan memiliki hasil lateks lebih tinggi dibandingkan dengan tanaman yang ditanam dengan jarak tanam yang sempit. Sedangkan menurut Schmole (1940) bahwa jarak tanam yang sempit menyebabkan kompetisi antar pohon sehingga mekanisme fisiologi pembentukan lateks dan aliran lateks menjadi terpengaruh. Siagian et al. (2005) juga menyatakan populasi tanaman yang tinggi akan mengakibatkan kompetisi terhadap hara dan ruang tumbuh, sehingga mempengaruhi pertumbuhan dan produksi tanaman. Dengan demikian, genotipe F1 hasil seleksi pada pengujian pada populasi semaian perlu dilakukan pengujian lanjutan dengan menggunakan jarak tanam yang dianjurkan dengan harapan akan dihasilkan kandidat klon dengan potensi hasil lateks dan pertumbuhan yang lebih baik.

\section{KESIMPULAN DAN SARAN}

Dari uraian di atas dapat ditarik kesimpulan yaitu sebagai berikut:

- Koefisien keragaman paling tinggi yang dihasilkan dari persilangan antar tanaman berkerabat jauh ditemukan pada karakter hasil lateks $(77,10 \%)$ dan ukuran lilit batang tanaman (29,32\%).

- Perbaikan terhadap karakter produksi melalui penggabungan 2 (dua) tetua yang berkerabat jauh belum menunjukkan peningkatan yang signifikan.

- Genotipe nomor G-17 dan G-80/2 merupakan genotipe hasil penggabungan dari 2 (dua) tetua yang mempunyai jarak 
genetik jauh yang berpeluang untuk dijadikan klon unggul baru.

Untuk mengetahui informasi yang lebih mendalam terhadap kedua genotipe terseleksi di pengujian evaluasi semaian tersebut, maka diperlukan pengujian pada skala yang lebih luas.

\section{DAFTAR PUSTAKA}

Aidi-Daslin, S. Woelan. and I. Suhendry. 2002. Report on the Evaluation and Utilization of the 1981 IRRDB Hevea Gerplasm in Indonesia. Paper on IRRDB Joint Workshop MalaysiaIndonesia. Kuala Lumpur, 28 August 7 September. Lembaga Getah Malaysia.: 10.

Aziz, A. SAK. 1998. Introducing Research Result into Practice. The Experience with Natural Rubber. In Aziz, A. SAK and Schiweltzer, D. T. (eds) Research Management. RRIM, Kuala Lumpur.

Borojevic, S. 1990. Principles and Methods of Plant Breeding. Elsevier Sci. Pub. Co. Inc. New York.

Crowder, L. V. 1986. Genetika Tumbuhan. Gadjah Mada University Press, Yogyakarta

d'Auzac, J. 2008. From Sucrose to Rubber: Hevea as a Green Rubber Factory. www.irrdb.com, diunduh tanggal 20 Januari 2008

Dijkman, M. J. 1951. Hevea. Thirty Years of Research in The Far East. University of Miami, Florida.

Goncalves, P. S., A. B. B. Cardinal., R. B. Dacosta., N. Bortoletto, and L. R. L. Gouvea. 2005. Genetic Variability and Selection for Laticiferous System Characters in Hevea brasiliensis. Genetic and Molecular Biology 28 (3) : 414-422.

Ho, C. Y. 1975. Clonal Character Determining The Yield Hevea brasiliensis. Proceeding International Rubber Conference. Kuala Lumpur, 7 8 January 1975. IRRDB.: 27-44
Madjid, A. 1985. Pelestarian Plasmanutfah Karet. Pros Lok. Nas. Pemuliaan Tanaman karet. Medan, 10 September. Pusat Penelitian Karet.: 163-177.

Mangoendidjojo. 2002. Dasar - Dasar Pemuliaan Tanaman. Kanisius, Yogyakarta

Novalina. 2009. Deteksi Marka Genetik yang Terpaut dengan Komponen Produksi Lateks pada Tanaman Karet (Hevea brasiliensis Muell Arg.) melalui Pemetaan QTL. Disertasi. Program Pascasarjana. Institut Pertanian Bogor, Bogor.

Oktavia, F., M. Lasminingsih, dan Kuswanhadi, 2010. Hubungan Kekerabatan Genetik antar Klon Karet sebagai Dasar Pemilihan Tetua untuk Mendapatkan Klon Unggul Lateks Kayu. Jurnal Penelitian Karet 28(2): 110.

Ong, S. H., R. Othman, and M. Benong. 1995. Status Report on the 1981 Hevea Germplasm Collection. Paper on IRRDB Annual Meeting and Symposium. Penang - Malaysia, 6 - 9 November. IRRDB.: 15.

Sayurandi dan Aidi-Daslin. 2011. Heterosis dan Heritabilitas pada Progeni F1 Hasil Persilangan Kekerabatan Jauh Tanaman Karet. Jurnal Penelitian Karet 29(1): 1-15.

Schmole, J. F. 1940. Kort Verslag Tot Ultimo 1939 Van de Toetstuinen Van Cloonen an Zaailing Families in Polonia. Arch Rubbercult. In Ned Indie 24: 455-470.

Siagian, N, I. Suhendry dan H. Munthe. 2005. Keragaan Pertumbuhan Beberapa Klon Anjuran Pada System Tanam Populasi Tinggi dan Berbagai Dosis Pupuk. Pros. Lok. Nas. Pemuliaan Tanaman Karet 2005. Medan, 22-23 Nopember. Pusat Penelitian Karet.: 227 - 250. 
Siregar, T.H.S., Tohari, H. Hartiko, dan Karyudi. 2007. Dinamika Perontokan Daun Pohon Karet dan Hasil Lateks: Jumlah Daun Rontok dan Hasil Lateks. Jurnal Penelitian Karet. 25(1): 45-58.
Woelan, S. dan R. Azwar. 1990. Kompatibilitas Kombinasi Persilangan dari Berbagai Klon Karet. Pros. Lok. Nas. Pemuliaan Tanaman Karet. Pontianak, 14-17 Juli. Pusat Penelitian Karet.: 174-189. 